\title{
Measuring the Impact of Church Externalities on House Prices
}

\author{
Gabriel K. Babawale \\ University of Lagos, Nigeria
}

\section{Background to the Study}

The notion of "externalities" is a useful concept developed in welfare economics. In real estate parlance, the notion states that external factors could impact on property value positively or negatively (Appraisal Institute, 2008; Do et al., 1994). Because of its physical immobility, real estate tends to be affected by externalities more strongly than most other economic goods, services, or commodities. Ascertaining the effects of externalities on property values provide a very strong test of the nuisance versus amenities effects. If an externality is truly a nuisance, then values of properties within close range will be adversely affected in proportion to the distance from it. If on the other hand an externality is an amenity, then property value will increase the closer a property is located to it. In this regard, location of churches within residential neighborhoods has been a subject of concern and a controversial issue in several jurisdictions.

Bell (2008) noted that there are over 200 impairments or detrimental conditions that can affect real estate value. Clear examples of externalities with negative effects on residential property values include landfill (Arimah \& Adinnu, 1995); brownfield (Kaufman \& Cloutier, 2006) contaminated properties (Kohlashe, 1991; Kinnard \& Geckler, 1991); air pollution (Hamilton \& Biggs, 1993; Komarova, 2009); industrial sites (Vor \& Groot, 2009); oil and natural gas facilities (Chan \& McMillian, 2004); and nuclear plant and iron and steel plant (Bilbao-Terol, 2009). On the other hand, land uses that usually constitute positive externalities include water view (Seiler et al., 2001; Paterson \& Boyle, 2002; Bourassa et al., 2004); open spaces, parks and greenbelt (Bolitzer \& Netusil, 2000; Asabere \& Huffinan, 2007); golf course (Nichollis \& Crompton, 2007); and neighbourhood schools (Ketkar, 1992; Zahirovic-Herbert, 2007). The question remains whether the externalities exhibited by churches are 
positive (amenities) or negative (nuisance or disamenities). Existing empirical studies are inconclusive and anecdotal evidences are mixed.

According to Do, Wilbur and Short, (1994), noise from church bells, loud speakers and musical instruments, people arriving and departing the premises, operating hours extending from morning till evening, and people of different shades and characters trooping into the neighborhood are parts of the negative externalities generated by neighborhood churches. Brogan (1991) also identified architectural incompatibility of church buildings with residential structures and the loss of view amenities, as some other negative effects of churches on residential property values. Other negative effects include the apparent traffic congestion on service days and other special events with the attendant parking problems and pollution from automobile exhaust, and in isolated cases, robbery attack within the vicinity. Nelson (2008) argued that environmental noises that exceed ambient levels can disturb valuable activities such as conversation, TV viewing, leisure, work or sleep and do in several cases have adverse effects on long-term health and thereby reduce productivity and quality of life. Irritating noise level in the neighborhood also contributes to more violent and aggressive behavior.

Churches on the other hand do exhibit certain potentially positive externalities. Thomas et al., (1996) concluded that neighborhood churches are amenities that enhance residential property values because they create positive externalities such as a symbol of morality while also serving as a hub of commercial activities that draws people together for worship and socials; providing peace in the form of a respite from commercial and family concerns; operating schools ranging from day-care for children and the aged, secondary and vocational, and in some cases, a university.

For long, the church has been indifference to environmental issues as the church tended to see ecological problem as something politicians had to deal with, not the church. According to Zizioulas (2013), the church has not appreciated the religious side of the environment. To some Christians, getting involved in the material environment moves you away from the spiritual; the latter considered as what really mattered. Some others considered the material enjoyment of life, which include the enjoyment of nature, as a sin. For most Christians, ecological issue is not just anything of importance; they cannot connect ecology with religion.

However, beginning from late 1980s, the green issues has gained increased attention of religious bodies; particularly the church in developed economies. 
For instance, a meeting on Patmos, jointly organized with Elliniki Etairia (Society for the Environment and Cultural heritage) brought together Hindus, Buddhists, Jews, Muslims and Christians, as well as artists and scientists to discuss the environment. This meeting led in 1991 to the Inter-Orthodox Conference on Environmental Protection held in Greece where it was officially declared for the first time that any damage to the environment constitutes a sin.

The green agenda of the Orthodox Church has been particularly practical and all-embracing. The church publishes guides to help parishes understand the large effects of small changes. The parishes were encouraged to think about the environment in whatever they do like using LED-lamps and turning off computers at the end of the day; making less use of car, but instead taking a walk, bike, bus or carpool; recycling paper, glass, metal and compostable organic waste; conserving water and energy within the church buildings; engaging young people and introducing educational tools.

At present, there is paucity of empirical studies on the impact of neighborhood churches on the values of nearby houses. Differences in socio-economic development as well as in cultural heritage between nations often influence people's perception and attitude towards the nuisance or amenities effects of neighborhood churches. In the more developed nations, the paucity of studies could be attributed to effective town planning (zoning regulation) which has considerably helped to curtailed indiscriminate location of religious premises. For example, the US has the Religious Land Use and Institutionalized Persons Act (RLUIPA) which makes churches adhere strictly to zoning regulations. Clowney (2007) observed that the Zoning Boards in America have so far successfully pressured religious institutions to limit their physical presence in cities and towns thereby making residential neighborhoods very reserved areas. It is therefore not surprising that only few studies have been carried out in the US on the subject. These include Do et al., (1994); Carroll, Clauretic and Jensen (1996); Ottensmann (2000); and the study by the Centre for Urban Policy and the Environment (2006).

Do et al., (1994) used information on 469 single-family residential dwellings sold in metropolitan Chula, Vista, California gathered between January 1991 and September 1992, to test the null hypothesis that proximity to a church building has no effects on residential property values. Using a standard hedonic pricing model, the study produced a regression equation for the natural logarithm of selling price in terms of externalities variables of distance and distance squared as follows: 
$\operatorname{Ln}(\mathrm{PS}) \ldots .+0.6008 * \operatorname{DJST}\left(10^{-4}\right)-3.5346 * \operatorname{DIST}_{1}^{2}\left(10^{-8}\right)(\mathrm{i})$

A significant positive value of the coefficient of D1ST in the resultant model (significant at the 5\% level), and negative coefficient of DJST (also significant at the $1 \%$ level) suggests that neighborhood churches exhibit negative externalities on single-family house prices with selling price of a home increasing with increased distance from a church building. Results indicate the effect of churches on sale prices is negative up to approximately 850 feet.

Carroll et al.,(1996) were inspired by the results of Do et al., (1984) to investigate the impact of neighborhood churches on residential property values using a sample of nearly 5,000 residential properly transactions in Henderson, Nevada, between January 1986 and December 1990. In contrast to the findings of Do et al., (1994), the study found that neighborhood churches are amenities that enhance property values by the positive extemalities they generate. They found out that people prefer to stay close to places of worship so as to reduce costs of commuting. Carroll et al., (1996) bolstered their findings by showing that distance from the site of a future church has little or no impact on residential property values, whereas distance from an existing church is associated with lower property values.

Curiously, Nigeria with very larger number of churches which are often planted indiscriminately within residential neighborhoods, the impact of church externalitiess on house prices has been only sparsely investigated. The only known study was conducted by Iroham and Oloyede (2010). The authors used the Living Faith Church, Ota, Ogun State, Nigeria to investigate the impact of churches on nearby residential property values. The study compared the mean of residential property values before and after the siting of the church, and suggested that the church had tremendous impact on the values of surrounding residential properties. This study exhibited apparent methodology limitations. Given that the factors affecting property values are many and diverse; the mean difference could not have captured the relative impact of the religious property on residential property values convincingly. Studies on the impact of externalities are traditionally investigated using the hedonic price model (Rosen, 1974; Kohlashe, 1991; Arimah \& Adinnu, 1995). The study is therefore neither persuasive nor conclusive. It is therefore still uncertain whether the eternalities generated by neighborhood churches are viewed by the market as positive or negative in Nigeria. Hence, the need for further studies on the subject.

This study empirically investigates the impact of selected churches in Lagos metropolis on prices of nearby residential properties. The paper is arranged in 
four sections. This introductory section is followed by a description of the study area. The study methodology including the description of the variables employed in the study occupy the third section, while section four includes the results, discussions and the conclusions.

\section{The Study Area}

The study area is Lagos metropolis. This study is particularly relevant and crucial to a nation like Nigeria, and especially metropolitan Lagos - the hub of Nigeria's commercial and industrial activities. First, in Nigeria, churches are built with little regards to zoning regulations such that religious premises are to be found dotted indiscriminately in virtually all residential neighbourhoods. Secondly, Nigeria is reputed as one the most religious nations in the world. Her Christian population is estimated at over 50 million (43\% of her 120 million total population), a large percentage of which are Pentecostals. In Nigeria, Pentecostal churches are particularly noted for unmatched zeal; exuberance; loud singing, clapping, bell ringing and drumming; and in some cases with loud speakers mounted on roof tops or on the facial boards. Weekly meetings for Pentecostal churches are numerous, besides the monthly or weekly vigils and conventions that draw adherences from across the country and beyond.

The Faith Tabernacle of the Living Faith Church, Ota, at the outskirt of Lagos and one of the numerous Pentecostal denominations in Lagos metropolis, is reportedly the largest church auditorium in the world (Guinness Book of Records, 2008); has over 1000 satellite fellowship centres dotted over Lagos and environs. An average of over 25, 000 vehicles (private and public) is said to enter the main church premises every Sunday for the three Sunday services in the 50,000-capacity auditorium. The Redeemed Church of God, another notable Pentecostal denomination, undoubtedly the fastest growing church denomination in the world, has over 2,500 church networks within Lagos metropolis alone, with congregation of less than 30 to over 3,500. The mission of this Pentecostal denomination is to have a church within five minute walking distance in all the major cities of Nigeria. These are just two out of hundreds of Pentecostal denominations fully represented within the metropolis. The impact of the externalities generated by these numerous centres of worship, indiscriminately dotted within residential neighbourhoods, on the values and pricing of nearby residential buildings as well as the challenges they pose to urban zoning policies in the study area cannot be over emphasized making it worthy of empirical investigation. 
Three large churches were selected for this study. These are: Mountain of Fire and Miracle Ministries, Onike; Deeper Life Bible Church, Gbagada; and Christian Pentecostal Mission, at Ajao Estate. Ajao Estate is predominantly a medium density residential neighbourhood with owner-occupied detached houses and rented apartment (flats) constituting the bulk of the property stock. It is the immediate residential neighbourhood to the Murtala Mohammed International Airport (Nigeria's chief airport). Majority of Ajao estate residents are within the middle income and the lower-upper income brackets. Gbagada, where the Deeper Life Bible Church locates, is an extensive and predominantly residential neighbourhood, a mixture of low and medium density residences. The immediate surroundings of the church under reference is predominantly medium density rented apartment. The Mountain of Fire and Miracle Church at Onike has immediate neighbourhood of medium density development comprising mainly of block of flats intermingled with detached houses and bungalows. The church shares boundary with the University of Lagos, by the University's second gate.

Each of the three churches has a large congregation going by the size of the church building, the volume of vehicular and human traffic generated at every church meetings and special events (frequency of meeting times vary but takes place, in some churches, virtually every day of the week). Large churches are chosen for the study because small churches are less intimidating to neighbourhood residents than large churches. Moreover, in Nigeria, and especially in Lagos metropolis, the impact of small churches on prices of neighbouring residential properties may be difficult to assess due to their large number, and their close juxtaposition. Carroll et al., (1996) is of the opinion that if noise and traffic is the major disruptions caused by churches, then we should expect that bigger churches would create correspondingly greater externalities. If larger churches generate greater externalities than smaller churches, as reported by Do et al., (1994), then larger churches should have greater impact (adverse) on the prices of neighbouring residential properties. If on the other hand, churches are amenities as Carroll et al., (1996) posited, then larger churches should enhance values of nearby properties more than smaller churches.

\section{Methodology}

In each of the study area, distance from church premises is measured in three concentric zones (A, B, C) of 50 metres, 100 metres, and 150 metres distance from the centre, respectively. The study population comprises of apartment (flats) within 150 metres of each church that were rented within the last 2 years 
prior to the survey. Using purposive sampling technique, 50 households' heads were served with questionnaires within each concentric zone making a total of 450 households for all the 9 zones for the three churches covered in the study. This sample size is considered reasonable given the homogeneous characteristics of the study areas. The sample objects (apartments (flats)), are also largely homogenous. The questionnaire sought information on net rental values and the attributes of residential property and was conducted over two (2) months (between June and July, 2010).

\section{Model Specification:}

The study employs the standard hedonic model to test the hypothesis that the presence of neighbourhood churches has no significant impact on the values of nearby residential properties. The hedonic model has remained the most adequate and well-accepted tool for untangling the cross-influences between the numerous attributes affecting property values and for establishing the implicit price of individual residential attributes (Des Rosiers et al., 2001). At its simplest, a hedonic equation is a regression of expenditure (rental or capital values) on the features or attributes that determine house rent or capital value. The model assumes that value of houses can be decomposed into the value of its constituent attributes (e.g. bedrooms, bathrooms, distance from amenities, age etc.) and provides estimates of the marginal contribution of each property attribute to house prices (Rosen, 1974).

The hedonic price model is of the form:

$\mathrm{P}=\beta_{\mathrm{o}}+\beta_{\mathrm{j}} \mathrm{X}_{\mathrm{j}}+\beta_{\mathrm{d}}+\mathrm{X}_{\mathrm{d}}+\mathrm{u}$

Where,

$\mathrm{P}=$ property value (the dependent variable).

$\beta \mathrm{o}=$ a constant term

$\beta_{\mathrm{j}}=$ estimated coefficients for continuous variables.

$\beta_{\mathrm{d}}=$ estimated coefficients for distance variable.

$\mathrm{X}_{\mathrm{j}}=\mathrm{jth}$ property characteristic.

$\mathrm{X}_{\mathrm{d}}=$ distance to church.

$\mathrm{u}=$ the error term.

\section{The Hedonic Variables}

Previous research has identified a number of housing attributes that impact on their prices. Kauko (2003) listed accessibility, neighbourhood quality, specific negative externalities, public service, taxes, and identity factors. McCluskey et al., (2000) in their study of Hong Kong housing market emphasized the date of sale, age of property, size, number of bedroom and bathrooms, number of 
garages, type of central heating, condition, neighbourhood and group cluster. Love (2000) in a similar Hong Kong study, classified residential property attributes into four categories namely: structural, physical, neighbourhood and environmental.

Bello (2008), a Nigerian study, grouped the attributes into those that are internal and those that are external to the property. Internal attributes is said to comprise the intrinsic characteristics of the property such as size, number of accommodation, condition, aesthetics, layout, age, and plot size, while external attributes include the general state of the economy, population, employment, immigration, finance, location, infrastructure, transportation and neighbourhood characteristics. Megbolugbe's (1988) study of the housing market in Jos, Nigeria, classified housing into three categories or traits: structural (square meters, building age, roof cover, and plumbing fixtures); neighbourhood (school quality, road quality, and availability of electricity, water and other vital public services); and locational (access to economic, social, and political activities such as distance to $\mathrm{CBD}$, shopping centres, parks, and other recreational facilities).

What can be drawn from these previous studies is that the housing attributes employed in a particular study would be those related and relevant to the specific market under consideration; reflecting the factors which significantly influence the expectations and perceptions of participants in that particular market. Since the main focus of this study is to measure the impact of church externalities on rental value of apartments, the hedonic equation for this study would be of the form:

$\mathrm{RV}_{1}=\mathrm{f}\left(\mathrm{X}_{\mathrm{jj}}\right.$ DIST $\left._{\mathrm{j}}\right)$

Where,

- $R V_{1}$ is the rental value of apartments (flats);

- $X_{\mathrm{ij}}$ is a set of explanatory housing-rent variables (housing/neighbourhood attributes) for a given property $\mathrm{i}$;

- $\mathrm{DIST}_{\mathrm{i}}$, is the distance of property $\mathrm{i}$ from the nearest church premises measured in meters (approximately).

The set of house rent variables considered relevant to the study area including their descriptions, codes, and measurements of various housing attributes are as shown in Table 1. Only those attributes which affect the prices paid for apartments, or the supply prices in the surveyed sub-market are included in the hedonic equation. Given paucity of secondary data on accommodation details, and lack of GIS resource, a number of continuous variables have to be approximated. 
Table 1: Definition of Hedonic Variables for the Study Area

\begin{tabular}{|l|l|l|}
\hline Variable Definition & $\begin{array}{l}\text { Variable } \\
\text { Code }\end{array}$ & Variable Measurement \\
\hline Net rental value/annum & Hp & Measure in Nigerian currency (N) \\
\hline Parking lots & PARKING & Number of car parking lots \\
\hline Bedrooms & ROOM & Number of bedrooms \\
\hline Bath/toilets & BATH & Number of bath/toilets \\
\hline Distance to work & DIS-WRK & Kilometres (approximately). \\
\hline
\end{tabular}

Perceived neighbourhood security

Armed robbers, area boys

\begin{tabular}{|l|l|l|}
\hline noise and flood nuisance) & SECURITY & 1 if adequate; otherwise 0 \\
\hline Nature/number of access roads & ACCESS & 1 if good; otherwise 0 \\
\hline Condition of property & COND & 1 if good; otherwise 0 \\
\hline Distance from the church & DREG & Metres (approximately). \\
\hline
\end{tabular}

Note:1US\$ = N150

Distance from church variable, DREG, captures the effect of proximity to a religious property on rental values of nearby residential properties. Other variables, apart from age and distance to work, are expected to have a positive influence on rental values. The age of property is however excluded from considerations because rental values (unlike capital values) respond rather to the condition of the property ('housing condition') than the age.

A significant positive coefficient value for DREG in the estimated model is a pointer to the nuisance effects of church externalities on house prices suggesting that rental value of a residential property increases as distance from a religious property increases. On the other hand, a significant negative coefficient is an evidence of positive externalities indicating that the rental value of a residential property decreases as distance from a religious property increases. 


\section{Results and Discussions}

The summarized statistics of the variables analyzed are presented in Tables 2-4. The F- statistics for the three models are highly significant at the $1 \%$ level, and $\mathrm{R}^{2}$ values are high and similar across the models suggesting that a very high significance could be placed on the results and that the eight housing attributes considered sufficiently account for variation in apartment rentals in each of the study area. Some of the variables exhibited unexpected signs in their correlations with housing price. The t-value column provides the individual significance of each independent variable in the regression equation and tells whether the variable is making statistically significant contribution. A variable must have a significant value of less than 0.05 to make significant unique contribution (Pallant, 2005). The Durbin-Watson value for each of the three models indicates that there are no autocorrelation among the independent variables.

Table 2. Regression Results: Mountain of Fire and Miracle Ministries

\begin{tabular}{|c|c|c|c|c|}
\hline Variable & beta weight & $\begin{array}{c}\underline{\text { beta }} \\
\text { coefficient }\end{array}$ & $\underline{\text { t-value }}$ & Sig. \\
\hline Constant & -374791.417 & -7.098 & .000 & \\
\hline No. of bedrooms & 204003.284 & 0.573 & 13.632 & .000 \\
\hline No. of bath/toilets & 168560.692 & 0.432 & 9.956 & .000 \\
\hline Distance to church & -393.018 & -067 & -2.222 & .028 \\
\hline House condition & -24042.375 & $-03 \mathrm{I}$ & -.996 & .321 \\
\hline Parking space & 7922,871 & .016 & .524 & .601 \\
\hline $\begin{array}{c}\text { Neighborhood security } \\
16024.329 \\
\end{array}$ & -025 & -850 & .397 & \\
\hline Road condition & 3452.602 & .005 & -177 & .859 \\
\hline Distance to work & I8563.160 & .038 & 1.244 & .216 \\
\hline
\end{tabular}

$\underline{\mathrm{R}}^{2}=0.881(88.1 \%) ;$ F-statistic $=130.519(\mathrm{p}>.000) ;$ Durbin Watson $=1.739 ;$ $\underline{1 \mathrm{US} \$=\mathrm{N} 150}$

Table 2 presents the summary of the results of the regression analysis for the Mountain of Fire and Miracle Ministries. Only three of the attributes make statistically unique contribution to house prices at $99 \%$ confidence level namely: number of bedrooms, number of toilet/bath, and distance from church.

The standardized beta coefficients which provide the order of importance or relative contribution of the housing attributes show that number of bedrooms make the largest contribution, followed by number of bath/toilet, and then the distance from church. The multiple regressions equation that relates house 
prices $(\mathrm{Hp})$ to the housing attributes is given by the constant and the coefficient of the unstandardized beta as:

$\mathrm{Hp}=-374791.42+20400.28 \mathrm{~N}_{\mathrm{r}}+168560.69 \mathrm{~N}_{\mathrm{bt} \_} 393,02 \mathrm{D}_{\mathrm{ch}}-24042.385 \mathrm{H}_{\mathrm{cd}}+$ $7922.87 \mathrm{P}_{\mathrm{lt}}-16024.33 \mathrm{~N}_{\mathrm{st}},+3452.6 \mathrm{OR}_{\mathrm{cd}}+18$

$563.16 \mathrm{D}_{\mathrm{Wl}}$

The equation shows that only the number of room, number of toilet/bath, availability of parking lot, condition of access road, and distance from work that are positively correlated to house price. One unit increase in the number of bedroom and bath/toilet results in N20,400.28 and N16,560.69 increase in house rent, respectively. The expected negative sign is found between house price and house condition but is not significant at the 0.1 level. The negative correlation of housing price with perceived level of security in the neighbourhood (though not statistically significant at the $1 \%$ level) is spurious. A combination of poor yields on investment properties (average $5^{1 / 2} \%$ per annum), high costs of maintenance, and tenants' poor capability to effect repairs even when it is their covenant responsibility, may be responsible for the low weight given to the condition of buildings given that high level of disrepair is today a commonplace. The apparent indifference to perceived level of security, according to the results, might not be unconnected with the general insecurity that envelops the entire nation, particularly, the urban centers.

More significantly, distance to church, our principal concern in this study, is negatively correlated contrary to the more popular belief. The negative coefficient (significant at $99 \%$ confidence level) indicates that apartment renters pay more for houses in close proximity to the church than those farther away. The 'unexpected' negative correlation can be attributed, in part, to the proximity of the church under consideration to the University of Lagos main campus, with its apparently stronger positive influence of the latter on house (particularly flats) prices. Shortage of campus accommodation for the ever growing number of both staff and students has continued to put pressure on available stock of residential accommodation within the university vicinity which is apparently strong enough to counter the negative externalities associated with the church on house prices. With supply outstripping demand, renters are apparently being 'forced' to play down on the negative externalities generated by the church. That may also inform why distance from work is positively correlated, though statistically insignificant. 
It may be reasonably concluded therefore that where negative and positive externalities locate in close juxtaposition, the ultimate effects on residential property values will depend on their relative impact.

Table 3. Regression Results: Deeper Life Bible Church, Gbagada

\begin{tabular}{|c|c|c|c|c|}
\hline Variable & beta weight & $\begin{array}{c}\text { beta } \\
\text { coefficient }\end{array}$ & $\underline{t \text {-value }}$ & $\underline{\text { Sig. }}$ \\
\hline Constant & -226948.999 & -2.521 & .013 & \\
\hline No. of bedrooms & 269152.485 & .611 & 10.327 & .000 \\
\hline No. of bath/toilets & 134979.236 & .303 & 5052 & .000 \\
\hline Distance to church & 309.802 & 044 & 1.024 & .308 \\
\hline House condition & -20871.869 & -032 & -737 & .426 \\
\hline Parking space & -70859.309 & -1.115 & -2.636 & .009 \\
\hline $\begin{array}{c}\text { Neighborhood security } \\
5060.783\end{array}$ & -008 & -0.183 & .855 & \\
\hline Road condition & -54838.142 & -007 & -1.807 & .073 \\
\hline Distance to work & -17184.475 & -030 & -0.0670 & .504 \\
\hline $\begin{array}{c}\underline{\mathrm{R}^{2}=0.751(75.1 \%) ; \quad \mathrm{F}-} \\
\underline{\text { statistic }=53.184(\mathrm{p}>.000)} \\
\frac{\text { Durbin Watson }=1.372 ;}{\underline{\text { USS } \$=\mathrm{N} 150}}\end{array}$ & & & & \\
\hline
\end{tabular}

Table 3 summarizes the results of the regression analysis for the Deeper Life Bible Church, Gbagada. Curiously, only three of the eight explanatory variables employed are positively correlated. These are number of bedrooms, number of bath/toilets, and distance from church.

The number of bedrooms again is the dominant factor followed by the number of toilet/baths. Surprisingly, perceived neighbourhood security level, availability of parking facilities, road condition and distance to work, are all negatively correlated. Though not statistically significant at the required level of confidence, the positive sign of the coefficient for distance from the church suggests that neighbourhood churches impact negatively on values of nearby residential properties such that house prices increase by approximately N310 for every additional one metre away from a church premises and vice-versa. The resultant regression equation is given as:

$\mathrm{Hp}=-226949.00+269152.49 \mathrm{~N}_{\mathrm{r}}+134979.24 \mathrm{~N}_{\mathrm{bt}}+309.80 \mathrm{D}_{\mathrm{ch}}-20871.87 \mathrm{H}_{\mathrm{cd}}-$ $70859.31 \mathrm{P}_{\mathrm{lt}}-5060.78 \mathrm{~N}_{\mathrm{st}}-54838.14 \mathrm{R}_{\mathrm{cd}}-17184,48 \mathrm{D}_{\mathrm{wk}}(\mathrm{vi})$ 
Table 4. Regression Results: Christian Pentecostal Mission

\begin{tabular}{|c|c|c|c|c|}
\hline$\underline{\text { Variable }}$ & $\underline{\text { beta weight }}$ & $\begin{array}{c}\text { beta } \\
\text { coefficient }\end{array}$ & $\underline{\text { t-value }}$ & Sig. \\
\hline Constant & -524066.528 & -6.245 & .000 & \\
\hline No. of bedrooms & 308790.550 & .675 & 11.513 & .000 \\
\hline No. of bath/toilets & 97071.684 & .224 & 3.843 & .000 \\
\hline Distance to church & 867.912 & .129 & 2.898 & .004 \\
\hline House condition & -44006.444 & -079 & 4.781 & .077 \\
\hline Parking space & 25294.920 & .046 & 1.018 & .310 \\
\hline $\begin{array}{c}\text { Neighborhood security } \\
1099.480\end{array}$ & .002 & .044 & .965 & \\
\hline Road condition & $-17409,120$ & -028 & -653 & .515 \\
\hline $\begin{array}{c}\text { Distance to work }-19538.958 \\
-.035-.807 .421\end{array}$ & & & & \\
\hline $\begin{array}{l}\text { R2=0.749 (74.9\%); F- } \\
\frac{\text { statistic }=52.538(\mathrm{p} .000) ;}{\text { Durbin Watson }=1.185 ;} \\
\underline{1 \mathrm{US} \$=\mathrm{N} 150}\end{array}$ & & & & \\
\hline
\end{tabular}

Table 4 summarises of the results of the regression analysis for Christian Pentecostal Mission; Ajao Estate. The D\$EG coefficient is positive and statistically significant at $99 \%$ confidence level throughout the entire study area suggesting that apartment renters viewed church in the neighbourhood as a disamenity that impact negatively on the prices of residential properties. Hence, rental value of a house increases as distance from church increases and viceversa.

$\mathrm{Hp}=-524066.53+308790655 \mathrm{~N}_{\mathrm{r}}+97071.68 \mathrm{~N}_{\mathrm{bt}}+867.91 \mathrm{D}_{\mathrm{ch}}-44006.44 \mathrm{H}_{\mathrm{cd}}+$ $25294.92 \mathrm{P}_{\mathrm{lt}}+1099.48 \mathrm{~N}_{\mathrm{st}}-17409.12 \mathrm{R}_{\mathrm{cd}}-19538.96 \mathrm{D}_{\mathrm{wk}}$

\section{Conclusions}

The pecuniary effects of environmental amenities (and disamenities) have attracted attention in economic and real estate literature, particularly with respect to their impact on house prices. There is a growing recognition that property development, use and management should be evaluated against criteria that embody sustainability measures. According to Boyd (2005), genuine sustainability evaluation should take place within a framework that incorporates three dimensions of performance - social, environmental and financial/ economic. In this regard, location of churches within residential neighbourhoods has been a contentious issue in several jurisdictions. This study empirically examines the effects of neighbourhood churches on rental values of nearby residential properties. Findings do not depart markedly from that of previous 
studies (Do et al., 1994) that neighbourhood churches generate more negative than positive externalities resulting in adverse effects on the prices of residential properties in close proximity. The exception to this rule, of course, is the overriding effects of more powerful positive externalities in close juxtaposition.

It is our conclusion therefore that churches generate more negative than positive externalities. However, the presence of a stronger positive externality could distort the result. The result of this study is beneficial to both public and private parties involved in land use decisions, especially, zoning. It will also assist the judiciary in resolving litigation bordering on the nuisance effects of churches within residential neighbourhood. Moreover, it is imperative that real estate valuers' appreciate the full import of externalities as part of their considerations in valuation of residential properties. Pearse (2005) argued that adequate pricing of externalities will have impact on both people's behaviour and the improvement of the environment. Given the ongoing global sustainability consciousness and drive, the real estate valuation profession would need to look beyond the traditional valuation factors and to review current valuation process and models to accommodate the different sustainability scenarios where key inputs are varied for differing environmental or social benchmark levels such as using weighted sustainability criteria (Boyd, 2005). The ability of valuers to rise up to this challenge will determine the place of the valuation profession in a world that is getting increasingly aware of the social, economic and environmental impacts of the property market. With globalization, international standards will be the platform upon which international valuations will be undertaken. It is imperative therefore that the Nigerian valuation practitioners adjust both theory and practice to comply with internationally accepted best practice. In addition, a wave of new laws and regulations as well as more effective enforcement procedure for existing environmental regulations may be required that would make churches adhere strictly to zoning. Such steps would help to establish the right link between nuisance and market values and thereby provide real estate valuers with the right framework for valuation of residential buildings affected by externalities as is already the practice in several economies. Such laws provide a market environment that makes the identification, evaluation and measurement of possible as well as probable adverse externalities generated by major land uses easier and more transparent.

Finally, further research is required to test the applicability of the study conclusions for other parts of the metropolitan Lagos. This study only examined the impact of church externalities on nearby residential properties (flats). It may be necessary to also investigate the effects of neighbourhood churches on other 
categories of residential properties and on non-residential properties in other parts of the metropolis.

\section{REFERENCES AND NOTES:}

Bell, R. (2008). Real Estate damages: Applied Economics and Detrimental Conditions. $\left(2^{\text {nd }}\right.$ ed.) Chicago: Appraisal Institute.

Boyd, T.P. (2005). Can we Assess the Worth of Environmental and Social Characteristics in Investment Property? A Paper Presented at 1 1th Pacific Rim Real Estate Society Conference.

Bourassa S.C., Hoesli, M. \& Sun, J. (2004). What's in a View? Environmental and Planning A. 36(8): pp 1427-50. Boxall, P. C., Chan, W. H., \&. McMillan, 1. (2005).

The Impact of Oil and Natural Gas Facilities on Rural Residential Property Values: A Spatial Hedonic Analysis. Resource and Energy Economic 27(4)248-269.

Carrol T.M.., Clauretie T.M., \& Jensen J. (1996). Living Next to Godliness: Residential Property Values and Churches. Journal of Real Estate Finance and Economics 12:319-330.

Dimke, M.S. (2008). Valuation of Tree Canopy on Property Values of Six Communities in Cincinnati, Ohio. Unpublished PhD. Dissertation, Ohio State University.

Do A. Q., Wilbur R.W., \& Short J. L. (1994). An empirical Examination of the Externalities of Neighbourhood Churches on Housing Values. Journal of Real Estate Finance and Economics, 9: 127-136.

Iroham, C.O. \& Oloyode, S. A. (2010). Location of Worship Centres and Its Effect on Residential Property Values (a case of Living Faith Church, Ota). A Paper Delivered at the First National Conference, Department of Urban and Regional Planning, University of Lagos. Emerging Global City: The African Challenge.

Ben C. A. \& Frank, I. A. (1995). Market Segmentation and the Impact of Landfills on Residential Property Valuers: Empirical Evidence from an African City. Journal of Housing and the Built Environment, 10(2):157-171.

Friso De Vor \& Henri L. F. de Groot. (2009). Impact of Industrial Sites on Residential Property Value: A Hedonic Pricing Analysis for the Netherlands. A Tinbergen Institute Discussion Paper.

Kaufman D. A. \& Cloutier N. R. (2006). The Impact of Small Brownfields and Greenspaces on Residential Property Values. Journal of Real Estate and Economics, 33: 19-30.

Kohihase, J. E. (1991). The Impact of Toxic Waste Sites on Housing Values. Journal of Urban Economics, 30(1):1-26.

Komarova V. (2009). Valuing Environmental Impact of Air Pollution in Moscow with Hedonic Prices. World Academy of Science, Engineering and Technology 57. 
Megbolugbe, I.F. (1989). A Hedonic Index Model: The Housing Market of Jos, Nigeria. Urban Studies Journal, 26;486.

Pallant, J. (2005). SPSS Survival Manual ( $2^{\text {nd }}$ ed.). UK: Open University Press.

Paterson R. W., \& Boyle, K. J. (2002). Out of Sight, Out of Mind? Using GIS to Incorporate Visibility in Hedonic Property Value Models. Land Economics, 78(3).

Richard C. R. (2005). Do Landfills Always Depress Nearby Property Values? Rural Development Paper (27). Rosen S. (1974). Hedonic Prices and Implicit Markets: Product Differentiation in Pure Competition. Journal of Political Economics, 82:34-55

Seiler, M. J., Bond, M. T., \& Seiter, V. L. (2001). The Impact of World Class Great Lakes Water Views on Residential Property Value. Appraisal Journal. 69(3):287-295.

Zizioulas, J (2013). The Green Church. Paper Presented at the Europa Nostra $50^{\text {th }}$ Anniversary Congress \& European Heritage Award Ceremony 2013, Athens, Greece.

\title{
SUMMARY
}

\section{Measuring the Impact of Church Externalities on House Prices}

\author{
Gabriel K. Babawale
}

\section{University of Lagos, Nigeria}

This study extends literature that empirically investigates the impact of the externalities generated by churches on prices of nearby residential properties with particular reference to selected areas in Lagos, Nigeria; but with some implications for economic studies in other parts of the world The study hypothesized that the proximity of a church has nosignificant effect (positive or negative) on house prices. The hypothesis is tested with a standard hedonic pricing model using the net rents of 450 apartments (flats) across the study area. The results confirmed the more common belief that neighborhood churches, particularly the larger ones, impact on the values of nearby residential properties negatively. It is further revealed that where a more powerful positive externalities exists side-by-side, the effects of the negative externalities can be considerably tempered or completely overshadowed. The results bring to light the environmental, social and economic (the triple bottom line) implications of the externalities generated by neighborhood churches in the study area. It is expected to assist urban planners, the courts, mortgagees and real estate valuers in resolving the controversies on the nuisance versus amenity effects of neighborhood churches.

Keywords: Churches, Externalities, Hedonic model, House prices. 